\title{
An Empirical Investigation of Culture and Guanxi Actions between China and Japan
}

\author{
Jing Jing Gong and Sadami Suzuki
}

\begin{abstract}
With the economic development of China, the Chinese culture have been interested by scholars and managers, especially the Guanxi culture which as a governance mechanism in doing business in China. This study intends to explore the influences of national culture on Guanxi actions between China and Japan. In order to investigate it, two surveys have been conducted to collect the data, one is for culture and the other one is for Guanxi actions. The result of national culture comparison shows both of two Chinese groups have a significant difference from Japanese but do not have significant difference between them. While, the comparison result of Guanxi actions reveals there is significant difference among three groups on Guanxi actions, but Chinese in China and Chinese in Japan do not share more similarities than Japanese. From the results may conclude that compared Guanxi actions, culture is more ingrain and robust, which is difficult to be changed by a different culture and business environment. Finally, the correlation analysis has been conducted between Hofstede cultural dimensions and Guanxi actions, which indicate that collectivism has significant influence on Guanxi actions.
\end{abstract}

Index Terms-Hofstede cultural dimensions, culture, collectivism, guanxi.

\section{INTRODUCTION}

With the development of economic globalization, it is very important for managers and researchers to understand the diversity of cultures among different countries in order to improve the competitive capability for multinational business. Especially, pay attention to the East Asia, where is a vital and expanding area for the fast growing economics in the world.

Numerous cross-cultural studies have demonstrated how people's communication styles in multinational business are influenced by their cultural expectations [1]. Hofstede [2] believes that the spread of business onto the global stage brings the issue of national and regional differences to the fore. According to his cultural dimensions research, culturally-based values systems comprise five dimensions, such as: (1) Power distance, (2) Individualism / Collectivism, (3) Masculinity / Femininity, (4) Uncertainty avoidance and (5) Long-term / Short-term orientation (Confucianism). Among these cultural dimensions, Individualism / Collectivism have served as a powerful theoretical construct for cross-cultural comparison of communication behavior.

As Japan is the developed country, whose economy

Manuscript received April 15, 2013; revised June 15, 2013.

The authors are with the Tokyo Institute of Technology, W9-61, 2-12-1, O-okayama, Meguro-ku, Tokyo, 152-8552, Japan (e-mail: hamigua89@gmail.com, suzuki.s.ag@m.titech.ac.jp). strength has taken over the past several decades in the world, even the Japanese culture has been recognized to represent the East Asian culture as a whole by many business leaders. However in recent years, notable industrial progress in China has also made Chinese business culture attract a wide business interest. Both Japan and China have been considered collectivistic societies, and both of their culture have been influenced by the Confucianism, which emphasizes the long-term orientation is different from the western behavioral tendency for short-term performances.

Guanxi is the personal relations or social connections in the Confucian society, which refers to a network of informal interpersonal relationships and exchange of favor established for the purpose of conducting business activities throughout China and East Asia [3]. Guanxi has been recognized as one of the major dynamics in the Chinese society where business behavior revolves around Guanxi, including not only the local firms, but also the foreign businesses [4].It is foremost a cultural concept that implies inter personal connections, but its underlying philosophy has dominated people's social and economic lives for a long time [5].

In this research, the first objective mainly focuses on if there are some significant cultural differences between Japan and China, both of whom represent collectivism societies. Since Guanxi is one of the important cultures in China which is influenced by the Confucian culture, therefore, the second objective of this study attempts to verify if Guanxi actions have significant differences between these two countries. Finally the relationship between Guanxi actions and collectivism orientation has been also discussed.

The rest of this paper is organized in the following order. The typologies of Guanxi have been discussed in the subsequent section together with the hypotheses proposed. And then, data collection process in Japan and China has been introduced. Data analysis including comparative analysis on cultural differences and Guanxi actions in different groups, the correlation analysis between collectivism orientation and Guanxi actions is outlined in the section four. The conclusions and future researches are given at the final section.

\section{LITERATURE AND RESEARCH HYPOTHESES}

\section{A. Cultural}

National culture is defined as the beliefs, values and assumptions perceived by people in their early childhood that later distinguish one group of people from another [2]. Because of the historical relationship between China and Japan, western researchers usually conclude the Eastern 
culture as one with minor difference in degree, however, as time goes, Confucianism thoughts have been gradually developing out their own behavioral modes and becoming part of social constraint for each region [6]. Although the features of Chinese and Japanese culture have been considered as Collectivism and Long-term orientation, which have been different from western behavioral tendency for Individualism and Short-term performance, each society has its separate, distinctive culture and philosophy that guide business performance [7].

As for Chinese society, whose culture sits in the higher rankings of Power distance representing people who live in this society believe inequality amongst people is acceptable and their respect of the rights of power and authority of those high social hierarchical standing. Although people have been in the pursuit of equal power and right, but the thousands of years' Confucian hierarchy culture is not easy to be changed at all. Whereas, Japan is constantly threatened by natural disasters from earthquakes, tsunamis, typhoon and so on, its culture presents high Uncertainty avoidance. People in this circumstance can't bear ambiguity, so they have a greater need for formal rules and absolute truth, and show less tolerance for people and groups with deviant ideas or behaviors. They also tend to accept less change, take fewer risks, avoid conflict and worry a lot about future.

Environmental factors such as institutional, economic, and social systems in different countries have influence on culture [8]. Some researchers pointed out culture are relatively stable even in the face of substantial change and turbulence [9], while, other researchers indicated culture may transcend national borders, compared with the cultural effects, the national effect is more influential [10]. Since there is little empirical work to investigate the culture difference between Chinese people at home and abroad, thus, this research is not only to demonstrate the cultural diversity between Chinese and Japanese, but also discuss the relationship between Chinese in China and Chinese in Japan. Therefore, the hypothesis 1 has been proposed:

Hypothesis 1: There is significant difference among three groups on culture dimension, but the Chinese in China and Chinese in Japan would share more similarities than Japanese.

\section{B. Guanxi}

Guanxi is one of the major dynamics in Chinese society where business behavior revolves around Guanxi. It is widely recognized that Guanxi is a key business determinant of firm performance because the life blood of the macro economy and the micro business conduct in the society is Guanxi network [4]. From a Chinese perspective social chaos is avoided, not by institutional law, but by an individual's acceptance of their proper place and role in society [11]. In such an environment business cannot be conducted without the facilitating role of Guanxi.

Guanxi is a very intricate and complicated conception to be defined. Generally speaking, the Chinese word Guanxi refers to the concept of drawing on connections to secure favors in personal relations, which contains implicit mutual obligation, assurance and understanding, and governs Chinese attitudes toward long-term social and business relationships [12]. Guanxi interaction has been viewed as idiosyncratic cultural phenomenon where Confucianism is the major life philosophy. In this Confucian society, in order to establish and maintain the hierarchical power structure, emphasize on collectivism and group harmony, the basic social norms of Guanxi is the Wulun relationship, that is, the monarch - subject, father - son, husband - wife, elder younger brothers and senior - junior friends, which defines Chinese relationships and sets the rules for each role playing. From the perspective of Chinese social progress, the "family - nation - world" is the structure from inside to outside where the family ethic is the basis of Confucius' human relations [6], [13]. Since the institutional environments influence Guanxi actions, thus, the following hypothesis has been extracted:

Hypothesis 2: There is significant difference among three groups on Guanxi actions, but the Chinese in China and Chinese in Japan would share more similarities than Japanese.

Guanxi in China, which is based on long-term orientation and mutual trust, is heterogeneous and more complicated than any kind of western interpersonal relationships [5]. As a collectivism society, the Chinese structure is organized by concentrical Guanxi circles, extending from family (the core) to relatives, friends, and so on, which is called "differentiated mode of association" [14]. This inequality may be traced back to the Confucian codification of interpersonal ties that define one's place in the hierarchy of social relationships [11]. Thus, according to the different tie of Guanxi base, Guanxi can be divided into the following categories.

TABLE I: A SUMMARY OF GUANXI'S CLASSIFICATION

\begin{tabular}{|l|l|}
\hline \multicolumn{1}{|c|}{ Guanxi's categories } & \multicolumn{1}{c|}{ Guanxi base } \\
\hline Hwang (1987) [15] & \\
\hline $\begin{array}{l}\text { (1) Expressive tie } \\
\text { (2) Instrumental tie } \\
\text { (3) Mixed tie }\end{array}$ & $\begin{array}{l}\text { (1) Family members and relatives } \\
\text { (2) Purely strangers } \\
\text { (3) Between the above both }\end{array}$ \\
\hline Yang (1993) [16] & \\
\hline $\begin{array}{l}\text { (1) Jia-ren Guanxi } \\
\text { (2) Qinqi Guanxi } \\
\text { (3) Pengyou Guanxi } \\
\text { (4) Sheng-ren Guanxi }\end{array}$ & $\begin{array}{l}\text { (1) Family members } \\
\text { (2) Relatives }\end{array}$ \\
\hline Tsang (1998) [17] & \begin{tabular}{l} 
(4) Mere acquaintances or strangers \\
\hline (1) Blood Guanxi
\end{tabular} \\
(2) Social Guanxi & $\begin{array}{l}\text { (1) Family members, relatives, } \\
\text { members of the same clan } \\
\text { (2) Members in a same organization }\end{array}$ \\
\hline $\begin{array}{l}\text { Su and Littlefield (2001) } \\
\text { [18] }\end{array}$ & \\
\hline $\begin{array}{l}\text { (1) Favoring-seeking Guanxi } \\
\text { (2) Rent-seeking Guanxi }\end{array}$ & \\
\hline Fan (2002a, 2002b) [19] [20] & \\
\hline $\begin{array}{l}\text { (1) Family Guanxi } \\
\text { (2) Helper Guanxi } \\
\text { (3) Business Guanxi }\end{array}$ & \\
\hline Chen and Chen (2004) [21] & \\
\hline $\begin{array}{l}\text { (1) Family Guanxi } \\
\text { (2) Familiar Guanxi } \\
\text { (3) Stranger Guanxi }\end{array}$ & $\begin{array}{l}\text { (1) Family members and relatives } \\
\text { (2) Former classmates, colleagues } \\
\text { demographic attributes }\end{array}$ \\
\hline Zhang and Zhang (2006) [5] & \\
\hline $\begin{array}{l}\text { (1) Qinqing Guanxi } \\
\text { (3) Jiaoyi Guanxi }\end{array}$ & $\begin{array}{l}\text { (1) Family members and relatives } \\
\text { (2) Fellow countrymen, classmates } \\
\text { or alumni, colleagues, etc } \\
\text { (3) Mere acquaintances }\end{array}$ \\
\hline
\end{tabular}

Guanxi is also a dynamic process and can be exchanged in some certain conditions [19], [20]. Simultaneously, in the 
collectivism society, the mutual trust between in-group and out-group is totally different. Therefore, in this research, according to the relationship from the inside of group to outside of group, Guanxi can be divided into 1) Guanxi based on strong tie (family members, relatives and intimate friends); 2) Guanxi based on middle tie (normal friends, neighbors, colleagues, classmates, etc); and 3) Guanxi based on weak tie (mere acquaintances or strangers). Hence, the following hypothesis has been put forward:

Hypothesis 3: Collectivism has some relationship with Guanxi, but, just has significant relationship with Guanxi based on strong tie, and no significant relationship with Guanxi based on middle and weak tie.

\section{MATHODOLOGY}

In order to test these hypotheses, a questionnaire survey research method was used to obtain the responses from China and Japan. As a data collection tool, a questionnaire was developed, which includes two parts, one is about the culture dimensions, and the other one is about the Guanxi actions. The culture dimensions encompass 14 assessment items based on four core assessment areas, which are chosen from Hofstede's cultural model. As well the Guanxi actions include 24 items based on three different kinds of Guanxi. Respondents are asked to choose their opinions about each sentence from "strongly disagree" to "strongly agree" in five point scales or seven point scales, respectively. (The questionnaire will be shown in the appendix).

The data collection has been started in July, 2012, both in Japan and China in the same time by the way of online survey. The data was collected from three groups: Chinese in China, Chinese in Japan, and Japanese. Most of the respondents are university students without working experience but all of the respondents are chosen randomly, with different ages, hometown, occupations, and so on. At the time of August, a total of 134 samples have been obtained from Chinese in China, 100 samples from Chinese in Japan and 104 samples from Japanese.

In order to ensure the reliability of questionnaire data which are used in this research, the Cronbach's coefficient alpha has been calculated during the data collection process.
Generally a value above 0.7 is considered adequate for internal consistency. The results are shown in terms of Cronbach's coefficient alpha at 0.6 for culture section and 0.884 from Guanxi section. These results indicate that high reliability of questionnaire in Guanxi section is ensured, but in culture section is not so good.

\section{DATA ANAlysis RESUlts AND Discussions}

\section{A. Culture Comparison among three Groups}

The purpose of this section is trying to verify the hypothesis 1 that there is significant difference among three groups on culture dimension, but Chinese in China and Chinese in Japan would share more similarities than Japanese. In order to testify it, the method of one-way analysis of variance (One - way ANOVA) is used among different groups and then the results shows in the Table II. As the results shown, all of groups have significant differences on these four culture dimensions, especially in the PDI and IDV dimension.

TABLE II: SUMMARY OF ANOVA TEST OF VARIABLES AMONG DIFFERENT GROUPS ON CULTURE

\begin{tabular}{|l|c|c|c|c|}
\hline & $\begin{array}{c}\text { Chinese } \\
\text { in China }\end{array}$ & $\begin{array}{c}\text { Chinese } \\
\text { in Japan }\end{array}$ & Japanese & F-value \\
\hline $\begin{array}{l}\text { Power distance } \\
\text { (PDI) }\end{array}$ & 7.78 & 8.57 & 10.13 & $\mathbf{2 2 . 2 6 * *}$ \\
\hline $\begin{array}{l}\text { Masculinity / } \\
\text { Femininity } \\
\text { (MAS) }\end{array}$ & 4.84 & 5.31 & 5.83 & $\mathbf{7 . 8 6 * *}$ \\
\hline $\begin{array}{l}\text { Individualism / } \\
\text { Collectivism } \\
\text { (IDV) }\end{array}$ & 7.60 & 8.10 & 9.28 & $\mathbf{2 2 . 1 0 * *}$ \\
\hline $\begin{array}{l}\text { Uncertainty } \\
\text { avoidance (UAI) }\end{array}$ & 13.41 & 12.49 & 13.16 & $\mathbf{4 . 4 6 *}$ \\
\hline \multicolumn{5}{|c|}{$* 5 \%$ significant $; * * 1 \%$ significant } \\
\hline
\end{tabular}

Then, the multiple comparisons among three groups are conducted and the results are shown in the Table III. From the results can be seen that, both Chinese in China and Chinese in Japan have a significant difference from Japanese except the UAI dimension, but both of these two Chinese groups do not have significant difference between each other also except the UAI dimension. Thus, the hypothesis 1 is confirmed.

TABLE III: MUlTiPle COMPARISONS BETWEen CHINESE IN CHINA, CHINESE IN JAPAN AND JAPANESE

\begin{tabular}{|c|c|c|c|c|c|c|c|c|c|}
\hline $\begin{array}{l}\text { Cultural } \\
\text { Dimension }\end{array}$ & $\begin{array}{c}\text { Chinese in } \\
\text { China }\end{array}$ & $\begin{array}{c}\text { Chinese in } \\
\text { Japan }\end{array}$ & $\begin{array}{c}\text { Mean } \\
\text { difference }\end{array}$ & $\begin{array}{l}\text { Chinese in } \\
\text { China }\end{array}$ & Japanese & $\begin{array}{c}\text { Mean } \\
\text { difference }\end{array}$ & $\begin{array}{c}\text { Chinese in } \\
\text { Japan }\end{array}$ & Japanese & $\begin{array}{c}\text { Mean } \\
\text { difference }\end{array}$ \\
\hline PDI & 7.78 & 8.57 & -0.79 & 7.78 & 10.13 & $-2.35 * *$ & 8.57 & 10.13 & $-1.56 * *$ \\
\hline MAS & 7.60 & 8.10 & -0.50 & 7.60 & 9.28 & $-1.67 * *$ & 8.10 & 9.28 & $-1.18 * *$ \\
\hline IDV & 4.84 & 5.31 & -0.47 & 4.84 & 5.83 & $-0.99 * *$ & 5.31 & 5.83 & -0.52 \\
\hline UAI & 13.41 & 12.49 & $0.92 * *$ & 13.41 & 13.47 & -0.06 & 12.49 & 13.47 & $-0.98 * *$ \\
\hline
\end{tabular}

As the results shown, most of scores for Chinese in Japan on those cultural dimensions are between the scores for Chinese in China and Japanese. According to some researches, traditional values and practices appear embedded in a country's social and economic institutions [22], and various social, economic, and political institutional forces derive at least partly from national culture. Furthermore, national culture may shape the nature and impact of management practices in that country [23], but difficult to be changed by a different culture and business environment totally. That is the reason why the scores of Chinese in Japan are between Chinese in China and Japanese on cultural dimensions.

\section{B. Guanxi Comparison among Three Groups}

In this section, in order to verify the hypothesis 2 that there 
is significant difference among three groups on Guanxi actions, but Chinese in China and Chinese in Japan would share more similarities than Japanese, the method of one-way analysis of variance has been used to do data analysis. The results are shown in the Table IV.

TABLE IV: SUMMARY OF ANOVA TEST OF VARIABLES AMONG DIFFERENT GROUPS ON GUANXI

\begin{tabular}{|l|c|c|c|c|}
\hline & $\begin{array}{c}\text { Chinese } \\
\text { in China }\end{array}$ & $\begin{array}{c}\text { Chinese in } \\
\text { Japan }\end{array}$ & Japanese & F-value \\
\hline $\begin{array}{l}\text { Guanxi based } \\
\text { on strong tie }\end{array}$ & 35.48 & 31.92 & 29.16 & $\mathbf{2 0 . 0 7 * *}$ \\
\hline $\begin{array}{l}\text { Guanxi based } \\
\text { on middle tie }\end{array}$ & 40.06 & 37.91 & 36.43 & $\mathbf{6 . 3 0 * *}$ \\
\hline $\begin{array}{l}\text { Guanxi based } \\
\text { on weak tie }\end{array}$ & 36.42 & 33.82 & 34.36 & 2.57 \\
\hline Total Guanxi & 111.96 & 103.65 & 99.95 & $\mathbf{1 0 . 7 5 * *}$ \\
\hline \multicolumn{5}{|c|}{$*: 5 \%$ significant $* * * 1 \%$ significant } \\
\hline
\end{tabular}

As the results represented in Table IV, Chinese in China take higher scores than Chinese in Japan and Japanese in all three kinds of Guanxi and total Guanxi. According to the result of F-value, three groups have significant differences on the Guanxi based on the strong and middle tie as well as total Guanxi, but no significant difference on the Guanxi based on weak tie.

Then, the multiple comparisons among three groups are also conducted, and the results are shown in the Table V. From the results can be seen that, the opinion to the Guanxi actions, the Chinese in China have significant difference with Chinese in Japan on the Guanxi based on strong tie and the total Guanxi, but have significant difference with Japanese on all of the Guanxi except the Guanxi based on the weak tie, however, Chinese in Japan just have significant difference with Japanese on Guanxi based on strong tie. Thus, the hypothesis 2 is just confirmed in a certain degree.

TABLE V: MUltiPle COMPARISONS BETWEEN CHINESE IN CHINA, CHINESE IN JAPAN AND JAPANESE

\begin{tabular}{|c|c|c|c|c|c|c|c|c|c|}
\hline $\begin{array}{l}\text { Cultural } \\
\text { Dimension }\end{array}$ & $\begin{array}{c}\text { Chinese in } \\
\text { China }\end{array}$ & $\begin{array}{c}\text { Chinese in } \\
\text { Japan }\end{array}$ & $\begin{array}{c}\text { Mean } \\
\text { difference }\end{array}$ & $\begin{array}{c}\text { Chinese in } \\
\text { China }\end{array}$ & Japanese & $\begin{array}{c}\text { Mean } \\
\text { difference }\end{array}$ & $\begin{array}{c}\text { Chinese in } \\
\text { Japan }\end{array}$ & Japanese & $\begin{array}{c}\text { Mean } \\
\text { difference }\end{array}$ \\
\hline Strong tie & 35.48 & 31.92 & $3.56^{*}$ & 35.48 & 29.16 & $6.31 * *$ & 31.92 & 29.16 & $2.76^{*}$ \\
\hline Middle tie & 40.06 & 37.91 & 2.15 & 40.06 & 36.43 & $3.63 *$ & 37.91 & 36.43 & 1.48 \\
\hline Weak tie & 36.42 & 33.82 & 2.60 & 36.42 & 34.36 & 2.06 & 33.82 & 34.36 & -0.535 \\
\hline Total Guanxi & 111.96 & 103.65 & $8.31 * *$ & 111.96 & 99.95 & $12.00 * *$ & 103.65 & 99.95 & 3.70 \\
\hline
\end{tabular}

Although both China and Japan have a collectivistic rather than an individualistic cultural value orientation, compared to China, Japan's legal system is more perfect. Even though China's legal system has been made great progress during these years, but, China is still typified as "government by people" whereas, Japan is typified as "government by law". In China, people in the social network are strongly bonded to have strong and clear role obligations, and hold high levels of trust, loyalty and altruism to people not to law. The Guanxi actions were more useful when the circumstance uncertainty was higher [24]. As well, people can transcend their own cultures and provided insights into another culture, but cannot replicate it directly and totally into another culture [1].

On the other hand, from the result can be seen that, the Guanxi actions between China and Japan are significant different except Guanxi based on the weak tie. That maybe because both China and Japan is the collectivism society and influenced by the Confucianism, both of theirs opinion to the relationship between in-group and out-group is totally different. Both of them don't trust the out-group too much, thus, the attitude to the Guanxi based on the weak tie is similar. The relationship between collectivism and Guanxi will be discussed in the next section.

\section{Correlation Analysis between Guanxi and Collectivism Orientation}

According to some research, Guanxi may lead to a strong in-group bias [25], [26], especially Chinese and Japanese are collectivistic with respect to their own group. In other words, Guanxi defines who are in group and who are out group. Thus, in order to verify the hypothesis 3 that Collectivism has some relationship with Guanxi, but, just has significant relationship with Guanxi based on strong tie, and no significant relationship with Guanxi based on middle and weak tie, the method of correlation analysis has been used in this section. The results of correlation analysis between collectivism and Guanxi are shown in the Table VI.

TABLE VI: CORRELATION ANALYSIS BETWEEN COLLECTIVISM AND

\begin{tabular}{|c|l|c|c|c|c|}
\hline \multicolumn{2}{|c|}{} & $\begin{array}{c}\text { Strong } \\
\text { tie }\end{array}$ & $\begin{array}{c}\text { Middle } \\
\text { tie }\end{array}$ & $\begin{array}{c}\text { Weak } \\
\text { tie }\end{array}$ & $\begin{array}{c}\text { Total } \\
\text { Guanxi }\end{array}$ \\
\hline \multirow{4}{*}{ IDV } & $\begin{array}{l}\text { Pearson } \\
\text { Correlation }\end{array}$ & $\begin{array}{c}\mathbf{- 0 . 1 6 9 *} \\
*\end{array}$ & -0.103 & -0.106 & $\begin{array}{c}\mathbf{- 0 . 1 5 1 *} \\
*\end{array}$ \\
\cline { 2 - 7 } & Sig. (2-tailed) & 0.002 & 0.059 & 0.052 & 0.005 \\
\cline { 2 - 7 } & N & 338 & 338 & 338 & 338 \\
\hline \multicolumn{7}{|c|}{$*: 5 \%$ significant $; * *: 1 \%$ significant } \\
\hline
\end{tabular}

As the result represented, the Individualism has significant negative relationship with Guanxi actions, especially with the Guanxi based on strong tie in a significant level, but no significant relationship with Guanxi based on middle and weak tie. The hypothesis 3 has been confirmed, which also means Guanxi based on strong tie is still more important than other types of Guanxi in the collectivism society of China and Japan. The result confirms it again, in the collectivism society people use Guanxi only with trustworthy partners, and relationship orientation is only applied to insiders of Guanxi network but not to outsiders of networks [27].To establish and develop Guanxi is to form the basis for a gradual transition from outsider to an insider so that a long-term relationship can be built [28].

\section{CONCLUSIONS AND FUtURE RESEARCH}

\section{A. Conclusions}

In this research, a questionnaire was utilized as an evaluate instrument to investigate the cultural differences including the Guanxi actions between China and Japan, as well as analyzed the relationship between Guanxi and collectivism orientation. The findings and implications were concluded as follows: 
First, the culture comparison among Chinese in China, Chinese in Japan and Japanese indicated that there is significant difference among three groups on culture dimensions, as well as, the culture dimensions between two Chinese groups don't have significant differences, but both of them have significant differences with Japanese. The result confirms that although the environment will influence culture and globalization has been radically taking place all over the world, each national culture still owns its uniqueness for its particular core value [6], and the core value of culture would be relatively stable even in the face of substantial change and turbulence [9].

Second, the Guanxi comparison among Chinese in China, Chinese in Japan and Japanese indicated that there is significant difference among three groups on Guanxi actions, but the Guanxi actions between Chinese in China, Chinese in Japan do not have more similarities than Japanese. People's behaviors will change if environment and business ethical changes. During the transition period of China, the policies and environment filled with uncertainty, Guanxi plays a bigger role in the business and social context, practically when the business environment is uncertain and adequate legal system is not available [29]. From the comparison results may conclude that compared to Guanxi action, culture is more ingrain and robust, which is difficult to be changed by a different culture and business environment.

Third, the correlation analysis between Guanxi action and collectivism orientation indicated that collectivism has a significant relationship with Guanxi, especially with Guanxi based on strong tie. Because in the collectivism society, people's attitude that the relationship between in-group and out-group is totally different. They share long-term orientation, mutual trust, loyalty and reciprocal with each other in-group much more than out-group. Guanxi plays a moderating role between in-group and out-group in the collectivism society. Understanding Guanxi and establishing it as a foundation for business activities is a key in Chinese business culture.

\section{B. Future Research}

According to some research, long-term orientation is another characteristic for China and Japan [2], [30] as well as, there is also some relationship between collectivism and long-term orientation [31]. Since Guanxi is a system of personal connections that carry long-term social obligations, thus, establish and maintain Guanxi will take lot of time and effort, especially for the people who are not the member of in-group. Because Guanxi functions well only in close Guanxi conditions in which interpersonal relationships are characterized primarily by strong tie and with minimal distrust, such as in-group relationships [32]. Therefore, the following research is to do some correlation analysis between Guanxi and long-term orientation.

Based on the cultural dimensions' average raw scores, the comparison results are different with Hofstede's research, that, China is a high PDI society than Japan, and Japan is a high UAI society than China, whereas, in this research, the results are reversed. On the one hand, that maybe, after the reform and opening-up in China, more and more freedom and equality thoughts have been accepted by Chinese people, the PDI should become smaller compared than before. As well, along with the growth of China's economy and competition intensifies, the sense of crisis and pressure is stronger in China, and people become more and more anxious for their life and future than before. Thus it may lead China to take higher score on UAI. On the other hand, all of Hofstede's data were collected from IBM company, and the participants were at different ages with work experiences. However, most of our respondents are university students without working experience, which may influence the results. Therefore, we hope to get more data in the future to do our research in a further step, especially from the people who are at different ages with work experiences.

\section{APPENDIX}

\section{A. Culture Section}

Please answer the following questions according to your thinking between $\mathrm{A}$ and $\mathrm{B}$.

\begin{tabular}{|c|c|c|c|c|c|c|}
\hline A & 1 & 2 & 3 & 4 & 5 & B \\
\hline $\begin{array}{l}\text { Inequalities between } \\
\text { people should be reduced } \\
\text { to a minimum }\end{array}$ & & & & & & $\begin{array}{l}\text { Inequalities } \\
\text { between people is } \\
\text { taken for granted }\end{array}$ \\
\hline $\begin{array}{l}\text { Children and their parents } \\
\text { should be equal } \\
\text { relationship }\end{array}$ & & & & & & $\begin{array}{l}\text { Children should } \\
\text { obey their parents }\end{array}$ \\
\hline $\begin{array}{l}\begin{array}{l}\text { Teachers and } \\
\text { should students } \\
\text { relationship }\end{array} \\
\text { be }\end{array}$ & & & & & & $\begin{array}{l}\text { Students should } \\
\text { respect teachers }\end{array}$ \\
\hline $\begin{array}{l}\text { Emphasis on the human } \\
\text { factor, intimate } \\
\text { relationships are more } \\
\text { important }\end{array}$ & & & & & & $\begin{array}{l}\text { Emphasis on } \\
\text { money and favor }\end{array}$ \\
\hline $\begin{array}{l}\text { Men and women must be } \\
\text { as responsible, ambitious, } \\
\text { resolute, caring and tender, } \\
\text { receptively }\end{array}$ & & & & & & $\begin{array}{l}\text { Men must be } \\
\text { responsible, } \\
\text { ambitious, } \\
\text { resolute; women } \\
\text { must be caring } \\
\text { and tender }\end{array}$ \\
\hline $\begin{array}{l}\text { Reconciliation and } \\
\text { negotiations to solve the } \\
\text { conflict }\end{array}$ & & & & & & $\begin{array}{l}\text { Duel and debate } \\
\text { to resolve } \\
\text { conflicts }\end{array}$ \\
\hline Easily influenced by others & & & & & & $\begin{array}{l}\text { Always go my } \\
\text { way }\end{array}$ \\
\hline $\begin{array}{l}\text { Tend to think in terms of } \\
\text { "we" }\end{array}$ & & & & & & $\begin{array}{l}\text { Tend to think in } \\
\text { terms of "I" }\end{array}$ \\
\hline $\begin{array}{l}\text { Relationship prevails over } \\
\text { task }\end{array}$ & & & & & & $\begin{array}{l}\text { Task prevails } \\
\text { over relationship }\end{array}$ \\
\hline $\begin{array}{l}\text { Uncertainty is a normal } \\
\text { feature of life, and is } \\
\text { accepted as it comes }\end{array}$ & & & & & & $\begin{array}{l}\text { The uncertainty } \\
\text { inherent in life is } \\
\text { a continuous } \\
\text { threat that must } \\
\text { be fought }\end{array}$ \\
\hline What is different is curious & & & & & & $\begin{array}{l}\text { What is different } \\
\text { is dangerous }\end{array}$ \\
\hline $\begin{array}{l}\text { There should be no more } \\
\text { roles than strictly } \\
\text { necessary }\end{array}$ & & & & & & $\begin{array}{l}\text { There is an } \\
\text { emotional need } \\
\text { for rules, even if } \\
\text { there were } \\
\text { implicit }\end{array}$ \\
\hline Low stress and low anxiety & & & & & & $\begin{array}{l}\text { High stress and } \\
\text { high anxiety }\end{array}$ \\
\hline $\begin{array}{l}\text { Competition among } \\
\text { colleagues is beneficial } \\
\text { rather than harmful }\end{array}$ & & & & & & $\begin{array}{l}\text { Competition } \\
\text { among colleagues } \\
\text { is harmful rather } \\
\text { than beneficial }\end{array}$ \\
\hline
\end{tabular}

\section{B. Cuanxi Section}

Please answer the following questions according to your situation from strongly disagree to strongly agree. The following table is about Guanxi based on Strong tie (Guanxi based on Middle tie / Weak tie are similar with this, due to 
space limitations, just omitted here).

\begin{tabular}{|c|c|c|c|c|c|c|c|}
\hline \multirow{2}{*}{\begin{tabular}{|l|}
\multicolumn{2}{|c|}{ A } \\
I want to obtain business information (on \\
government policies/market trends etc.) \\
by using my relationship with my \\
family/relatives
\end{tabular}} & 1 & 2 & 3 & 4 & 5 & 6 & 7 \\
\hline & & & & & & & \\
\hline $\begin{array}{l}\text { I want to obtain business opportunities } \\
\text { (job hunting/promotion etc.) by using my } \\
\text { relationship with my family/relatives. }\end{array}$ & & & & & & & \\
\hline $\begin{array}{l}\text { I want to solve some business problems } \\
\text { (hefty fine/punish/some actions against } \\
\text { rules etc.) by using my relationship with } \\
\text { my family/relatives. }\end{array}$ & & & & & & & \\
\hline $\begin{array}{l}\text { I think such kinds of actions above are } \\
\text { general in my country. }\end{array}$ & & & & & & & \\
\hline $\begin{array}{l}\text { I think such kinds of actions above are } \\
\text { correct. }\end{array}$ & & & & & & & \\
\hline $\begin{array}{l}\text { Keeping in touch or emotional } \\
\text { communication is very important to } \\
\text { maintain my relationship with my } \\
\text { family/relatives. }\end{array}$ & & & & & & & \\
\hline $\begin{array}{l}\text { Giving a gift or help each other is very } \\
\text { important to maintain my relationship } \\
\text { with my family/relatives. }\end{array}$ & & & & & & & \\
\hline $\begin{array}{l}\text { Giving interests and benefits to each } \\
\text { other is very important to maintain my } \\
\text { relationship with my family/relatives. }\end{array}$ & & & & & & & \\
\hline
\end{tabular}

\section{REFERENCES}

[1] C. Hui and G. Graen, "Guanxi and professional leadership in contemporary Sino-American joint ventures in mainland China," Leadership Quarterly, vol. 8, no. 4, pp. 451-465, 1997.

[2] G. Hofstede, "Cultural constraints in management theories," The Academy of Management Executives, vol. 7, no. 1, pp. 81-94, 1993.

[3] S. Lovett, L. C. Simmons, and R. Kali, "Guanxi versus the market: ethics and efficiency," Journal of International Business Studies, vol. 30, no. 2, pp. 231-248, 1999

[4] Y. D. Luo, "Guanxi: principles, philosophies, and implications," Human Systems Management, vol. 16, no. 1, pp. 43-51, 1997.

[5] Y. Zhang and Z. G. Zhang, "Guanxi and organizational dynamics in China: a Link between individual and organizational levels," Journal of Business Ethics, vol. 67, pp. 375-392, 2006.

[6] M. L. Wong, "Guanxi management in lean production system-an empirical study of Taiwan-Japanese firms," American Journal of Economics and Sociology, vol. 69, no. 3, pp. 1079-1106, 2010.

[7] G. Hofstede, Culture's consequences, comparing values, behaviors, institutions, and organizations across nations, Thousand Oaks, CA: Sage Publication, 2001.

[8] J. L. Farth, P. C. Earley, and S. C. Lin, "Impetus for actions: A cultural analysis of justice and organizational citizenship behavior in Chinese society," Administrative Science Quarterly, vol. 42, pp. 421-444, 1997.

[9] S. Ward, C. Pearson, and L. Entrekin, "Chinese cultural values and the Asian meltdown," International Journal of Social Economics, vol. 29 no. 3, pp. 205-217, 2002.

[10] J. Tan, "Culture, nation and entrepreneurial strategic orientations: implications for an emerging economy," Entrepreneurship Theory and Practice, pp. 95-111, summer, 2002.

[11] M. Y. Lee and E. Paul, "Insider-outsider perspectives of Guanxi," Business Horizons, pp. 25-30, Jan-Feb, 2000.

[12] A. Millington, M. Eberhardt, and B. Wilkinson, "Gift giving, Guanxi and illicit payments in buyer-supplier relations in China: analyzing the experience of UK companies," Journal of Business Ethics, vol. 57, pp. 255-268, 2005.

[13] L. H. Lin, "Cultural and organizational antecedents of Guanxi: the Chinese cases," Journal of Business Ethics, vol. 99, pp. 441-451. 2011.

[14] X. T. Fei, From the soil: the foundation of Chinese society, Berkeley: University of California Press, 1992.

[15] K. K. Huang, "Face and favor, the Chinese power game," American Journal of Sociology, vol. 92, no. 4, pp. 944-974, 1987.

[16] K. S. Yang, "Chinese social orientation: an integrative analysis," in L. Y. Cheng, F. M. C. Cheung, and C. N. Chen, Eds., Psychotherapy for the Chinese: Selected Papers from the First International Conference (The Chinese University of Hong Kong, Hong Kong), pp. 19-56, 1993.

[17] E. W. K. Tsang, "Can Guanxi be a source of sustained competitive advantage for doing business in China?" The Academy of Management Executive (1993-2005), vol. 12, no. 2, pp. 64-73, 1998.
[18] C. Su and J. E. Littilefield, "Entering Guanxi: a business ethical dilemma in mainland China," Journal of Business Ethics, vol. 33, no. 3 , pp. 199-210, 2001

[19] Y. Fan, "Questioning Guanxi: definition, classification and implications," International Business Review, vol. 11, pp. 543-561, 2002.

[20] Y. Fan, "Guanxi's consequences: personal gains at social cost," Journal of Business Ethics, vol. 38, no. 4, pp. 371-380, 2002.

[21] X. P. Chen and C. C. Chen, "On the intricacies of the Chinese Guanxi: a process model of Guanxi development," Asia Pacific Journal of Management, vol. 21, no. 3, pp. 305-324, 2004.

[22] C. F. Fey, M. Y. S. Park, and H. J. Bjorkman, "Opening the black box of the relationship between HRM practices and firm performance: a comparison of MNE subsidiaries in the USA, Finland, and Russia,' Journal of International Business Studies, vol. 40, no. 4, pp. 690-712, 2009.

[23] C. Wu, J. J. Lawler, and X. Yi, "Overt employment discrimination in MNC affiliates: home-country cultural and institutional effects," Journal of International Business Studies, vol. 39, no. 5, pp. 294-772. 2008.

[24] L. A. Keister, "Guanxi in business groups: social ties and the formation of economic relations," in Social Connections in China, Cambridge University Press, 2002, ch. 4, pp. 77-96.

[25] P. C. Earley, "East meets west meets Mideast: further explorations of collectivistic and individualistic work groups," Academy of Management Journal, vol. 36, pp. 319-348, 1993.

[26] P. C. Earley, "Self or group: cultural effects of training on self-efficacy and performance," Administrative Science Quarterly, vol. 39, pp. 89-117, 1994.

[27] J. L. Zhang and N. Pimpa, "Embracing Guanxi: the literature review," International Journal of Asian Business and Information Management, vol. 1, no. 1, pp. 23-31, 2010.

[28] G. T. Haley, C. T. Tan, and U. C. V. Haley, New Asian emperors: the overseas Chinese, their strategies and competitive advantages, Butterworth-Heinemann, Oxford, 1998.

[29] K. C. P. Lee and K. P. Humphreys, "The role of Guanxi in supply chain practices," International Journal of Production Economics, pp. 450-467, 2006.

[30] S. H. Schwartz, "Beyond individualism and collectivism: New cultural dimensions of values, Individualism and Collectivism: Theory Method and Applications," Newbury Park, CA: Sage, pp. 85-122, 1994.

[31] J. W. Kwon and H. C. Kim, "Do China, Korea and Japan form a cultural cluster?" in Proceedings of 3rd Asia-Pacific Business Research Conference, 2013.

[32] D. Y. Lee and P. L. Dawes, "Guanxi, trust, and long-term orientation in Chinese business markets," Journal of International Marketing, vol. 13, no. 2, pp. 28-56, 2005.

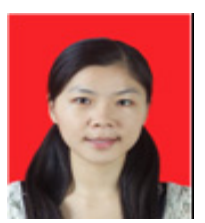

Jingjing Gong was born in China in 1983. She is a doctoral course student in the Department of Industrial Engineering and Management, Graduate school of Decision Science and Technology, Tokyo Institute of Technology, Japan. She received her bachelor degree and master degree in Jilin University, China in 2007 and 2009 respectively. Now, her research areas focus on logistics and supply chain management, new product development and cultural researches. During these two years, she attended international conference and made presentation for three times. The following paper has been published: Supply Chain Operational Performance and Its Influential Factors: Cross National Comparison between Japan and China. Brazilian Journal of Operations \& Production Management. Volume 8, No. 2, 2011, pp. 67-87. The following has been accepted in 2012. 07: The Impact of Ownership Status and Regional Differences on SCM Operational Performance in China. Information.

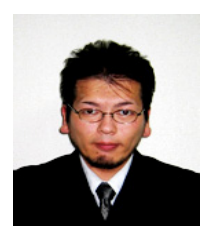

Sadami Suzuki was born in Japan in 1973. He is an Associate Professor in Industrial Engineering and Management, Graduate school of Decision Science and Technology, Tokyo Institute of Technology, Japan. He received his B. Eng., M. Eng. and Dr. Eng. from Tokyo Institute of Technology in 1998, 2000, and 2007 respectively. His research areas focus on production and operations management, customer satisfaction and loyalty, and supply chain management. Assoc. Prof. Suzuki is a member of Japan Industrial Management Association (JIMA), Japanese Operation Management and Strategy Association (JOMSA) and Japanese Society for Quality Control (JSQC). He received research award of JIMA in 2006 by the paper entitled "Quantifying the Bullwhip Effect in a Supply Chain with a Periodic Review System", Journal of Japan Industrial Management Association, 56 (3), pp.147-154 (2005). 